\title{
Developing EAL Learners' Intercultural Sensitivity Through a Digital Literacy Project
}

\section{Angelica Galante}

Language and culture are informally integrated in many English as an Additional Language (EAL) programs, but cultural discussions are often regarded from the perspective of a particular dominant culture. Although this integration is crucial for the development of communicative competence, practical applications are still challenging as language teachers tend to know more about linguistic items than cultural aspects (Celce-Murcia, 2007). This article describes a digital literacy project implemented with language learners in an adult EAL program. Using Bennett's (1993) DMIS model for intercultural sensitivity, the project invited international students and newcomers to Canada to explore and expand on their understanding of intercultural relationships while studying in a multicultural EAL class. The learners engaged in 5 steps to complete the project (reflective discussion, script writing, video recording scenes, editing, and final reflection), with a short movie serving as the digital product. The digital literacy project is proposed as a potential tool for integrating intercultural sensitivity into EAL programs and engaging learners in discussions about diversity in cultural values, beliefs, and behaviours as a way to affirm their cultural and intercultural identities.

Alors que plusieurs programmes d'anglais langue additionnelle (ALA) intègrent informellement la langue et la culture, les discussions portant sur la culture adoptent souvent le point de vue d'une culture dominante particulière. Bien que cette intégration soit cruciale pour le développement de la compétence communicative, les applications pratiques demeurent un problème de taille puisque les enseignants de langue ont généralement plus de connaissances relatives à la langue qu'à la culture (Celce-Murcia, 2007). Cet article décrit un projet d'initiation au numérique mis en œuvre auprès d'apprenants adultes dans un programme d'ALA. S'appuyant sur le modèle DMIS de Bennett (1993) de sensibilité interculturelle, le projet visait à encourager des étudiants internationaux et des nouveaux arrivants au Canada à approfondir leurs connaissances des rapports interculturels tout en poursuivant leur apprentissage dans une classe d'ALA multiculturelle. Les étudiants ont suivi les 5 démarches du projet (discussion de réflexion, rédaction de scénarios, enregistrement vidéo de scènes, édition et réflexion finale) pour arriver à la production d'un court-métrage. Nous proposons ce projet d'initiation au numérique comme outil pouvant appuyer l'intégration de la sensibilité interculturelle dans les programmes d'ALA et inciter les étudiants à discuter de diversité en matière de valeurs, croyances et comportements culturels afin d'affirmer leurs identités culturelles et interculturelles. 


\section{Canada's Multilingual and Multicultural Identity}

In the Canadian 2011 census, more than 200 languages were reported as a home language or mother tongue, with Tagalog, Mandarin, Hindi, Arabic, Creoles, Bengali, Persian, Spanish, Urdu, and Russian as the top $10 \mathrm{immi-}$ grant languages (Statistics Canada, 2012). This linguistic diversity, inherent in the Canadian context, has the potential to grow exponentially given that people from other countries continue to choose Canada as their country of residence, seeking professional and educational experiences. In 2012, Canada hosted 265,400 international students, and Canada's international education strategy is to nearly double this number by 2022, aiming to attract many to become permanent residents in Canada (Canada's International Education Strategy, 2014). International students and newcomers to Canada bring many benefits to the country (e.g., economic), in addition to the rich contributions to Canada's multicultural identity.

As previously noted, Canada is linguistically and culturally diverse, and English as an Additional Language (EAL) classrooms in this country are no exception; these classrooms are often composed of individuals representing several linguistic and cultural backgrounds. Recent reports from prominent North American (American Council on the Teaching of Foreign Languages, 2006), European (Council of Europe, 2001), and international (UNESCO, 2009) educational organizations agree that making use of this diversity for a critical analysis of cultural and intercultural dialogues is timely. In this sense, a focus on the development of intercultural sensitivity is a means to facilitate such dialogues.

\section{Culture and Language Teaching}

Before exploring how intercultural sensitivity can be integrated into the EAL classroom, the concept of "culture" needs careful consideration. Readers of the TESL Canada Journal might recall discussions that evolved after Courchêne's (1996) limited notion of culture and the teaching of "Canadian" culture in EAL programs, which caused strong reactions (Sauvé, 1996; Taylor, 1997; Walsh-Marr, 2011). Although Courchêne rightly admits that language teachers "must challenge the dominant cultural paradigm" (p. 14), he seems to support the overt teaching of the dominant culture to new Canadians "as a kind of safety net to avoid embarrassing themselves and others" (p. 13). For example, he suggests that traditions such as Christmas, along with its history, from religion to commercialization (e.g., gift exchanges and Santa Claus), should be taught to new Canadians. In response to Courchêne's inadvertent claims, Walsh-Marr (2011) points out that EAL professionals should keep away from monolithic views of culture and from teaching "cultural do's and don'ts" (p. 118). Culture is a complex concept with many facets that can be interpreted in relation to different aspects: "the other," ethnicity, cus- 
toms, traditions, social and geographical contexts, as well as values (Bennett, 1993; Byram, 1991; Nieto, 2010). In the field of intercultural communication, a distinction between objective and subjective culture has been made to help clarify what intercultural studies entail. Objective culture includes aspects such as politics, economy, food, and art, while subjective culture includes aspects related to people's worldviews, such as values, beliefs, and behaviours (Bennett \& Bennett, 2004). Although knowledge of objective culture can certainly increase one's cultural knowledge, understanding subjective culture "can provide access to the differing cultural experience of others and enable mutual adaptation" (Bennett \& Bennett, 2004, p. 150). The project described in this article was designed with the aim of providing EAL students with an opportunity to explore and expand on different views of subjective culture, including values, beliefs, and behaviours. For the purposes of this project, focusing on a particular dominant culture would not be suitable, given that the nature of both the EAL classroom and the Canadian context are multicultural. In an earlier article (Galante, 2014a), I argued that cultural awareness is integral to language teaching in the 21st century and that interculturality is one important dimension necessary for communicative competence.

Over the years, the communicative competence model has been reconceptualized (Canale, 1983; Canale \& Swain, 1980; Celce-Murcia, 1995; CelceMurcia, Dörnyei, \& Thurrell, 1995; Celce-Murcia \& Olshtain, 2000), and intercultural communication has been recognized as an important dimension of communicative competence (Celce-Murcia, 2007). Although culture and language are tightly linked (Byram, 1991; Kramsch, 1993; Nieto, 2010) and culture is generally seen as an integral dimension in language teaching (Byram \& Morgan, 1994; Celce-Murcia, 2007), the development of intercultural awareness is often disregarded in many language learning programs because most teachers tend to know more about the target language than about its sociocultural aspects (Celce-Murcia, 2007). In addition, few prescriptive guidelines with comprehensive sets of instructions on how to teach intercultural competence are available. In fact, top-down guidelines, if available, should be mindfully used, as the overt teaching of a target culture (a.k.a. dominant) in relation to others requires cultural sensitivity on the part of the facilitator (Fowler \& Blohm, 2004). Valuing the cultural perspectives and experiences of international students and newcomers to Canada is necessary when introducing cultural dimensions of the host country. Language learning contexts, including multicultural EAL classrooms, are a perfect place to promote intercultural dialogues, and participatory projects therein can help students become culturally sensitive.

\section{Intercultural Sensitivity}

The terms intercultural sensitivity, intercultural communicative competence (ICC), cross-cultural adaptation, and transcultural communication have been 
used interchangeably in the literature on intercultural studies (Sinicrope, Norris, \& Watanabe, 2007), and several models of intercultural competence have been conceptualized. Spitzberg and Changnon (2009) have categorized these models as five different types: co-orientational (e.g., Byram, 1997), developmental (e.g., Bennett, 1993), compositional (e.g., Deardorff, 2006), causal (e.g., Arasaratnam, 2006), and adaptational (e.g., Kim, 1988). Although all of these models have been used in intercultural research, Bennett's (1993) developmental model of intercultural sensitivity (DMIS) outlines a progression from one's view of the world (ethnocentric) toward increasing cultural awareness (ethnorelative), which was helpful to inform the conceptualization of the digital literacy project described in this article. Essentially, the DMIS includes three ethnocentric stages - denial, defense, and minimization of cultural differences - and three ethnorelative stages-acceptance, adaptation, and integration of cultural difference-as illustrated in Figure 1.

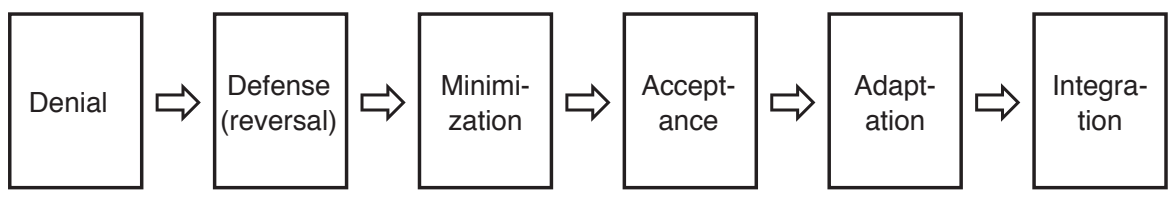

Ethnocentric Stages

Ethnorelative Stages

Figure 1: Developmental Model of Intercultural Sensitivity adapted from Bennett (1986)

Hammer, Bennett, and Wiseman (2003) have briefly described the six stages of Bennett's (1993) model: in the denial stage, one perceives the real culture to be his/her own and there is an unawareness of or disinterest in other cultures. In the defense stage, only one culture (one's own) is viable and there is the idea of "us" and "them." In the minimization stage, features of one's own culture are taken as universal; one expects similar behaviour from others and may even insist on correcting others' behaviour to match their own. In the acceptance stage, one understands that one's own culture is just one among many others and accepts cultural differences, although not necessarily agreeing with them. In the adaptation stage, one's worldview expands and empathy toward others' cultures is expressed. In the last stage, integration, different cultural worldviews are included in one's own, with none being central. Ultimately, the goal of intercultural reflections is to avoid stereotypes and individual "labels" and to expand on worldviews (Bennett \& Bennett, 2004).

\section{Critical Incidents and Critical Literacy in the Digital Age}

Many international students and newcomers to Canada express difficulties communicating with people in their new environment. They are often puz- 
zled when misunderstandings occur while interacting with students from other countries and/or with local people, resulting in a lack of understanding about why such problems have occurred. Although there exist several effective methods for intercultural training, critical incidents is particularly helpful to clarify misunderstandings between people from different cultural backgrounds. Critical incidents uses "situations in which there is a problem of cross-cultural adaptation or misunderstanding, problem, or conflict arising from cultural differences between interacting parties" as a preamble to develop intercultural awareness (Fowler \& Blohm, 2004, p. 58). The expected outcome of using critical incidents in intercultural training is to "increase participants' understanding of their cultural and personal attitudes and beliefs as well as those of others" (Fowler \& Blohm, p. 58). I used this method to design the digital literacy project, as many EAL students often express their concerns about communicating with Canadians and people from other countries, particularly in understanding different values, beliefs, and behaviours. I also followed Freire's seminal concept of critical literacy (1970) to offer a strong foundation for the analysis of the relationships among students and the community. Through critical literacy, students are required to openly express their ideologies, beliefs, values, cultures, and identities. Identity in language learning has been a significant dimension in discussions of language and culture in the past decade (Cummins, 2001; Norton, 2013; Norton \& Toohey, 2011), and negotiating identities can be particularly beneficial in multicultural classrooms where students can voice and expand on beliefs, values, and issues from a cultural standpoint. Hence, more than 40 years later, Freirean critical literacy is still thriving, but now with the advantage of involving more communities through digital literacy.

Digital literacy does not only include the knowledge of using computers, mobile phones, and other digital tools but also includes a social dimension that involves people's relationships, interactions, and "social identities" (Jones \& Hafner, 2012, p. 13). Digital literacy can promote active participation by members of a given community, which may range from the local classroom to a larger one that crosses geographical boundaries (e.g., via social media). In the context of language learning, video and movie projects have been gaining popularity as innovative ways to promote digital literacy among language learners (Cummins \& Early, 2010; Darvin \& Norton, 2014; Lotherington, 2011; Lotherington \& Jenson, 2011; Toohey, Dagenais, \& Schulze, 2012). Toohey et al. (2012) have suggested that, through digital literacy, language learners can develop critical reflections and higher levels of literacy, as the use of "linguistic, cultural, material, visual, and gestural sources" is needed to deliver the message to an intended audience (p. 86). The digital literacy project described below is an example of how intercultural sensitivity can be integrated into EAL programs - particularly, but not exclusively, among adult learners - where cultural diversity, ideologies, and identities are negotiated. 


\section{The Project}

\section{Context}

The project has been piloted and repeatedly used with international students and newcomers to Canada in an advanced EAL program in a college in Ontario. It is a 14-week program offered to students who need to improve linguistic skills and meet the necessary language requirements to enter postsecondary education.

\section{Reasons for Designing the Project}

As previously noted, when choosing a particular method for intercultural training, teachers/facilitators must consider the desired outcomes and what they expect their learners will achieve (Fowler \& Blohm, 2004). My decision to carry out this project stemmed from two main goals: (a) to provide students with an opportunity to use academic vocabulary - one of the requirements of the program -in a meaningful way; and (b) to increase students' intercultural sensitivity based on students' own critical incidents. Hence, I decided to design a digital literacy project that included both academic vocabulary practice and intercultural reflections.

\section{The Digital Literacy Project in 5 Steps}

The project involved five steps, completed halfway through the program, over a period of 6 weeks.

Step 1: Reflective discussion. In Week 8, a project entitled "Your difference is the difference" was introduced to students with a set of steps to be completed (see Appendix A). I prepared these guidelines to help students with time management while completing the project. Most students seemed interested in the project but, as expected, were unsure about their preliminary digital literacy competencies, which at this stage involved video recording and editing. I stressed that both content and language use were more important than the technical digital requirements of the final product. As well, I offered to help in the video recording and editing processes, if needed. Students were then invited to take part in the first step, the reflective discussion. Working in groups of four or five, they explored their own critical incidents: cross-cultural issues or misunderstandings encountered while living in Canada. During the discussion, I created a slideshow with emerging themes posited by the groups, which was later used to provide ideas for the digital literacy project. The first step of the project included the first three ethnocentric stages proposed by Bennett's (1993) DMIS model: denial, defense, and minimization of cultures. Students suggested topics from their own negative/conflicting experiences such as problems relating with others, politeness vs. rudeness, and different values and beliefs. Interaction included relations with people such as homestay family members, students in class, teachers and staff members, friends, 
families, and people in public realms (e.g., restaurants, stores, post offices). I facilitated the discussions by asking additional questions to engage students in critical reflective processes. Questions such as Why do you believe this issue happened? Why do you believe people think differently about the same issue? and To what extent have the issues occurred due to different cultural viewpoints? guided the reflection. The main purpose of this discussion was to provide students with an opportunity to reflect on cultures from an ethnocentric view toward ethnorelativism. For example, one topic discussed included homestay family members not allowing international students to cook their own food in the home due to strong smells. In this case, students explained that cooking and eating food from their country of origin was a necessary ritual that affirmed their identity. Subsequently, they discussed their perceptions of why this had been an issue, and later concluded that their homestay family members were probably unaware of students' cultural relationship with food. Although this reflective discussion was not (yet) intended to explore processes of adaptation or to encourage cultural assimilation, some possible solutions to conflicts started to emerge: first, students suggested telling their homestay family members the importance of cooking food from their countries; then, if negotiation was not an option, they suggested choosing another homestay family with whom to live. This step allowed students to expand on intercultural relationships, reflect on their cultural identities, and consider solutions for conflicts. The discussion took approximately 30 minutes and was essential to move toward ethnorelativism. The topics of discussion would become the basis for the script produced.

Step 2: Script writing. During Week 9 of the EAL program, students chose the members of the class with whom they wished to work, although a few students preferred to work alone as they wanted to express their perceptions of different cultures from an individual viewpoint. The slideshow with emerging critical incidents created in Step 1 was used to help students make a decision about which topics to include in their video. At this point, they were reminded that the audience would be the other students in class, but they would also be able to share it with a larger community via YouTube if they wished to do so. Students were allowed a few minutes of class time to make decisions regarding the topics, the storyline, and the format of the video. For example, in one video a group of students chose a talk show where one host would interview international students about their perceptions of beauty (Galante, 2014b). In another video, a student chose to show three stages that, in her viewpoint, helped her accept, adapt, and integrate into a culturally diverse setting (Galante, 2014c). Once the topic decision was made, students started writing their script. Some students worked together to write every single line of the script, while others preferred to divide the work among group members, with each person writing one sketch. I walked around the classroom and guided them during the writing process. To ensure that their stories were moving from ethnocentric to ethnorelative views, I asked ques- 
tions such as Why do you think people behave that way? (denial: unawareness of other cultures), If this incident annoyed you, could it be a result of different worldviews about the same issue? (defense: cultural differences may be threatening), Why do you think people should behave like you do? (minimization: universal behaviour), and What can be done to solve this issue? (adaptation and integration). These questions aimed to help students understand the intercultural dimensions of the situations. I also suggested adding introductions to their stories with the clear aim of making it more comprehensible to their audience, while at other times I suggested rewriting or reorganizing thoughts or ideas that seemed unclear. The decision to use written scripts rather than improvised speech stemmed from two reasons. (a) In a previous project, students' improvised speech at times impaired comprehension due to inappropriate use of grammar or unclear messages. This caused frustration among students in the audience, as part of the project included a final reflection about their classmates' videos. (b) The EAL program requires that students use academic vocabulary items, and I aimed to read their scripts to ensure good command of the use of these words. Because most students were unable to finish writing the entire script in class, they met outside class time during Week 10 to finalize this process and subsequently submitted it to me electronically. Once I received the scripts, I used the Track Changes feature in Microsoft Word to make suggestions: for example, I asked students to elaborate on topics that seemed unclear, to reflect on their critical incidents, and to revise sentence structure, grammar, and/or misspelled words. After reviewing the scripts, I sent them back to the students electronically so they could revise them prior to video recording the scenes. As noted, Step 2 included a reflection on critical incidents during the script writing, and a reflection about the same issues during the script revision. These two reflective processes were essential to guide students to move from ethnocentric to ethnorelative cultural views. While the first step of the project focused on the stages of denial, defense, and minimization proposed by Bennett's (1993) DMIS model, the second step introduced the stages of acceptance, adaptation, and integration of cultures. The next two steps of the project, as described below, focused on the use of digital literacies as a process of mediation for expressing students' own accounts of their intercultural sensitivity.

Step 3: Video recording. This occurred in Week 11. Although I informed students they could borrow digital cameras provided by the college, they all preferred to use their own mobile devices to record the scenes. Prior to Step 3 , several samples of YouTube videos were shown in class to help students explore different stylistic and multimedia strategies. For example, students observed the use of transitions, background music, subtitles, and camera angles. The step of video recording the scenes was completed outside class time. All of the students were enrolled in a full-time program that required them to be available from 8:30 a.m. to 6:30 p.m. to attend classes. As they sometimes had a one- or two-hour break between classes, they often met their group mem- 
bers during this time or after classes, depending on their availability. Thus, the process of video recording the scenes was done autonomously.

Step 4: Editing the video. This step was expected to be completed during Week 12. The editing consisted of arranging the previously video recorded scenes into one single movie file. I assumed that some students might not have editing skills, so I recommended a few editing tutorials on YouTube to encourage learner autonomy. I also offered to assist with the editing process as a last resort. My assistance was not needed, as one or more people in each group had the necessary digital skills to edit their videos. The video editing software used included Movie Maker, iMovie, and YouTube editor. Students were not expected to exhibit professional quality digital editing skills; rather, the focus was on a shift from ethnocentric to ethnorelative views of culture to develop intercultural sensitivity.

Step 5: Watching and reflecting. In Week 13, during a two-hour class, students watched one another's videos and completed a reflection on each. Prior to showing the videos, a reflection sheet with the following five questions was distributed to each student in class:

1. What are the critical incidents raised in this video and how do they relate to different cultural worldviews?

2. How important is the discussion of these issues for you as a resident in Canada?

3. In your viewpoint, what was (were) the most significant message(s) in this video?

4. What (if any) were the negative factors during the completion of this assignment?

5. What (if any) were the positive factors during the completion of this assignment?

Overall, students expressed satisfaction with the assigned project. Most importantly, many indicated the relevance of discussing issues related to intercultural relations and their identities as international students and newcomers in Canada. Through the last step of the project, students were able to explore and reflect on both their own critical incidents and those of their peers. In other words, they navigated through the six stages of Bennett's (1993) DMIS model. In addition, after watching their peers' videos, most students reported experiencing situations similar to those of their peers. They found learning strategies of adaptation and integration to a new environment particularly helpful. Ultimately, the last step of the project helped students expand on their understanding of intercultural relationships through others' experiences; more specifically, moving from ethnocentrism toward ethnorelativism, students reported that differences and similarities are in the eye of the beholder and insightfully concluded that respecting and accepting people's differences is the preferred practice to accept, adapt, and integrate into another culture. 


\section{Conclusion}

Language and culture are inextricably intertwined, and exploring cultural and intercultural dimensions in language learning is crucial, particularly in multicultural contexts. In culturally diverse countries such as Canada, engaging international students and newcomers to Canada in a reflective discussion about intercultural sensitivity can help them voice and expand their worldviews. In this sense, projects that combine intercultural sensitivity with language learning provide a unique opportunity for students to understand, respect, and value cultural diversity. In addition, through the exploration of intercultural sensitivity, these students can accept and integrate different cultural views into their own, which facilitates adaptation to a new environment. Certainly, integrating intercultural sensitivity in the EAL classroom does not guarantee critical incidents will not occur; rather, this integration allows a reflective opportunity to, quoting one of the participants of the project, "accept and recognize the huge diversity of sociocultural differences ... different styles of life, perceptions of life, and different nations here in Canada" (Galante, 2014c, section 6.05).

The digital literacy project described in this article has many potential uses in EAL programs, particularly in culturally diverse classrooms. Revisiting Bennett's (1993) DMIS model, this project allowed students to move from ethnocentricism toward ethnorelativism: they explored the early stages of denial, defense, and minimization, and gradually developed the stages of acceptance, adaptation, and integration of cultures. By positioning themselves in relation to cultural awareness, students learned about their own culture and that of the other, interpreting and relating to other cultures while using an additional language (English) to reflect on their cultural identities. This critical self-awareness empowered students to reflect on intercultural relations both inside and outside of the classroom. When communicating with people from diverse cultural backgrounds in Canada and/or in other countries, students can identify cultural differences, accept that cultures may have distinct worldviews, and express empathy toward others. In addition, the digital literacy project was used as a mediating tool that provided students an opportunity to experience intercultural sensitivity through their peers' critical incidents. As digital literacies can eliminate "boundaries of time and space" (Jones \& Hafner, 2012, p. 13), the videos produced by the students (available on YouTube) are valuable resources for other EAL students in Canada and in other countries.

Although this digital literacy project was implemented with advanced EAL learners in a Canadian college, it could be adapted and/or modified to suit other classrooms. Important considerations should include the learning context (e.g., foreign, English-speaking), number of students in class, and schools' infrastructure and resources (e.g., digital cameras, computers). It is important to note that teachers leading this digital literacy project should 
have a sound understanding of Bennett's (1993) DMIS model and use it as a theoretical framework through the stages of the project described in this article. As well, it is important that teachers both be clear about the goals of the project and have patience to allow participants time to reflect on their own development of intercultural sensitivity. It is also suggested that projects like the one described in this article be developed over a considerable amount of time. This project is simply one of several possibilities of integrating intercultural sensitivity and language learning, and need not be replicated in its entirety. Rather, teachers must reflect on students' needs, context, and identities, with potential for creating a similar project in which critical and digital literacies are applied. Integrating intercultural sensitivity in EAL programs may seem complex, but providing an opportunity for students to affirm their cultural identities and respect cultural diversity is the ultimate reward. It is also hoped that projects that facilitate the development of intercultural sensitivity, such as the one described in this article, can equip students with effective intercultural skills to support them in social, educational, and professional contexts in both Canada and other countries.

\section{Acknowledgements}

I am grateful to the dedicated students who participated in this project, particularly the ones who gave me permission to share their projects online. I thank the anonymous reviewers for many insightful comments and suggestions on a previous draft. Their suggestions have greatly improved the content of this article. I would also like to thank Dr. Marian Rossiter, the editor, for her encouraging comments.

\section{The Author}

Angelica Galante is a $\mathrm{PhD}$ candidate in Language and Literacies Education at OISE-University of Toronto. Her current research interests include intercultural sensitivity, digital literacies, plurilingual education, and identity in language learning.

\section{References}

American Council on the Teaching of Foreign Languages. (2006). Standards for foreign language learning in the 21st century (3rd ed.). Yonkers, NY: National Standards in Foreign Language Education Project.

Arasaratnam, L. A. (2006). Further testing of a new model of intercultural communication competence. Communication Research Reports, 23(2), 93-99. doi:10.1080/08824090600668923

Bennett, M. J. (1986). A developmental approach to training for intercultural sensitivity. International Journal of Intercultural Relations, 10(2), 179-196. doi:10.1016/0147-1767(86)90005-2

Bennett, J. M., \& Bennett, M. J. (2004). Developing intercultural sensitivity: An integrative approach to global and domestic diversity. In D. Landis, J. M. Bennett, \& M. J. Bennett (Eds.), Handbook of intercultural training (3rd ed., pp. 147-165). Thousand Oaks, CA: Sage.

Bennett, M. J. (1993). Towards ethnorelativism: A developmental model of intercultural sensitivity. In R. M. Paige (Ed.), Education for the intercultural experience (2nd ed., pp. 21-71). Yarmouth, ME: Intercultural Press.

Byram, M. (1991). Teaching culture and language: Towards an integrated model. In D. Buttjes \& M. Byram (Eds.), Mediating languages and cultures (pp. 17-32). Clevedon, UK: Multilingual Matters. 
Byram, M. (1997). Teaching and assessing intercultural communicative competence. Clevedon, UK: Multilingual Matters.

Byram, M., \& Morgan, C. (1994). Teaching-and-learning language-and-culture. Clevedon, UK: Multilingual Matters.

Canada's International Education Strategy. (2014). Harnessing our knowledge advantage to drive innovation and prosperity. Retrieved from http://international.gc.ca/global-markets-marchesmondiaux/education/strategy-strategie.aspx?lang=eng

Canale, M. (1983). From communicative competence to communicative language pedagogy. In J. Richards \& R. Schmidt (Eds.), Language and communication (pp. 2-27). London, UK: Longman.

Canale, M., \& Swain, M. (1980). Theoretical bases of communicative approaches to second language teaching and testing. Applied Linguistics, 1(1), 1-48. doi:10.1093/applin/1.1.1

Celce-Murcia, M. (1995). The elaboration of sociolinguistic competence: Implications for teacher education. In J. E. Alatis, C. A. Straehle, B. Gallenberger, \& M. Ronkin (Eds.), Georgetown University round table on languages and linguistics 1995 (pp. 699-710). Washington, DC: Georgetown University Press.

Celce-Murcia, M. (2007). Rethinking the role of communicative competence in language teaching. In E. Alcon Soler \& M. P. Safont Jordà (Eds.), Intercultural language use and language learning (pp. 41-57). Amsterdam, Netherlands: Springer.

Celce-Murcia, M., Dörnyei, Z., \& Thurrell, S. (1995). Communicative competence: A pedagogically motivated model with content specifications. Issues in Applied Linguistics, 6(2), 5-35.

Celce-Murcia, M., \& Olshtain, E. (2000). Discourse and context in language teaching: A guide for language teachers. New York, NY: Cambridge University Press.

Council of Europe. (2001). Common European Framework of Reference for languages: Learning, teaching, assessment. Cambridge, UK: Cambridge University Press.

Courchêne, R. (1996). Teaching Canadian culture: Teacher preparation. TESL Canada Journal, 13(2), 1-16.

Cummins, J. (2001). Negotiating identities: Education for empowerment in a diverse society (2nd ed.). Los Angeles, CA: California Association for Bilingual Education.

Cummins, J., \& Early, M. (Eds.). (2010). Identity texts: The collaborative creation of power in multilingual schools. Stoke-on-Trent, UK: Trentham Books.

Darvin, R., \& Norton, B. (2014). Transnational identity and migrant language learners: The promise of digital storytelling. Education Matters, 2(1), 55-66.

Deardorff, D. K. (2006). Identification and assessment of intercultural competence as a student outcome of internationalization. Journal of Studies in International Education, 10(3), 241-266. doi:10.1177/1028315306287002

Fowler, S. M., \& Blohm, J. M. (2004). An analysis of methods for intercultural training. In D. Landis, J. M. Bennett, \& M. J. Bennett (Eds.), Handbook of intercultural training (3rd ed., pp. 37-84). Thousand Oaks, CA: Sage.

Freire, P. (1970). Pedagogy of the oppressed. New York, NY: Seabury Press.

Galante, A. (2014a). English language teaching in the post-method era. Contact, 40(3), 57-62.

Galante, A. (2014b). Intercultural sensitivity in EAL learning -Video 1 [Video file]. Retrieved from https://www.youtube.com/watch?v=XEG5SiMtDLQ

Galante, A. (2014c). Intercultural sensitivity in EAL learning - Video 2 [Video file]. Retrieved from https://www.youtube.com/watch?v=Ej8ySpDwUTg

Hammer, M. R., Bennett, M. J., \& Wiseman, R. (2003). Measuring intercultural sensitivity: The intercultural development inventory. International Journal of Intercultural Relations, 27(4), 421-443. doi:10.1016/S0147-1767(03)00032-4

Jones, R. H., \& Hafner, C. A. (2012). Understanding digital literacies: A practical introduction. New York, NY: Routledge.

Kim, Y. Y. (1988). Communication and cross-cultural adaptation: An integrative theory. Philadelphia, PA: Multilingual Matters. 
Kramsch, C. (1993). Context and culture in language teaching. Oxford, UK: Oxford University Press. Lotherington, H. (2011). Digital narratives, cultural inclusion, and educational possibility: Going new places with old stories in elementary school. In R. Page \& B. Thomas (Eds.), New narratives: Stories and storytelling in the digital age (pp. 254-276). Lincoln, NE: University of Nebraska Press.

Lotherington, H., \& Jenson, J. (2011). Teaching multimodal and digital literacy in L2 settings: New literacies, new basics, new pedagogies. Annual Review of Applied Linguistics, 31, 226-246. doi:10.1017/S0267190511000110

Nieto, S. (2010). Language, culture, and teaching: Critical perspectives (2nd ed.). New York, NY: Routledge.

Norton, B. (2013). Identity and language learning: Extending the conversation (2nd ed.). Bristol, UK: Multilingual Matters.

Norton, B., \& Toohey, K. (2011). Identity, language learning, and social change. Language Teaching, 44(4), 412-446. doi:10.1017/S0261444811000309

Sauvé, V. (1996). Working with the cultures of Canada in the ESL classroom: A response to Robert Courchêne. TESL Canada Journal, 13(2), 17-23.

Sinicrope, C., Norris, J., \& Watanabe, Y. (2007). Understanding and assessing intercultural competence: A summary of theory, research, and practice (Technical Report for the foreign language program evaluation project). Second Language Studies, 26(1), 1-58.

Spitzberg, B. H., \& Changnon, G. (2009). Conceptualizing intercultural competence. In D. K. Deardorff (Ed.), The Sage handbook of intercultural competence (pp. 2-52). Thousand Oaks, CA: Sage.

Statistics Canada. (2012). Linguistic characteristics of Canadians. Retrieved from http://www12. statcan.gc.ca/census-recensement/2011/as-sa/98-314-x/98-314-x2011001-eng.cfm

Taylor, L. (1997). "Canadian culture," culture difference, and ESL pedagogy: A response to Robert Courchêne and Virginia Sauvé. TESL Canada Journal, 15(1), 70-76.

Toohey, K., Dagenais, D., \& Schulze, E. (2012). Second language learners making video in three contexts. Language and Literacy, 14(2), 75-96.

UNESCO. (2009). UNESCO world report: Investing in cultural diversity and intercultural dialogue. Paris, France: Author. Retrieved from http://unesdoc.unesco.org/images/0018/001847/184755e.pdf

Walsh-Marr, J. (2011). Keeping up the conversation on culture: A response to Robert Courchêne and others. TESL Canada Journal, 29(1), 113-120.

\section{Appendix A \\ Video Project: "Your difference is the difference"}

In groups of 4 or 5 , create a video on the topic of "Your difference is the difference." You may want to choose one the themes below:

$\begin{array}{ccc}\text { documentary(non-fiction) } & \text { talk show } & \text { comedy } \\ \text { fiction } & \text { humanitarian } & \text { interview }\end{array}$

\section{These are the steps:}

- In Week 8, your group will present your topic and a brief oral reflection on a critical incident;

- In Weeks 9 and 10, your group will meet in the lab (or out of class time if necessary) to write your script; once the script is finished, you should submit it to your instructor electronically for review;

- In Week 11, you will video record the movie out of class time;

- In Week 12, you will edit your movie out of class time;

- In Week 13, you will submit the movie to your instructor. In the same week, your video will be watched by the members of the class; then, you will write a reflection on all of the videos. 


\section{Video requirements}

- The video must be 10-15 minutes long with good audio quality;

- The video must address the topic of intercultural relations with a reflection on critical incidents;

- The scripts must be original, and all members must contribute an equal amount of effort;

- Include a minimum of 10 (or 2 per person) academic words you have learned in class;

- Include other communicative strategies learned in class: body language, voice projection, eye contact, expressing emotions;

- The movies can be filmed with cell phones, digital cameras, webcams, or camcorders;

- All steps must be followed on the dates suggested;

- You are encouraged to use special effects, background music, costumes, lighting, computer graphics, and/or make-up;

- You are welcome to be creative. 